Барна М. Ю., martabarna@ukr.net, ORCIDID:0000-0001-5248-9774,

Researcher ID: G-9493-2019,

д.е.н., проф., периий проректор, професор кафедри туризму та готельно-ресторанної справи, Львівський торговельно-економічний університет, м. Львів

\title{
КОНЦЕПТУАЛЬНІ ОЗНАКИ МІГРАЦІЙНИХ ПРОЦЕСІВ ЯК ОБ’ЄКТА ДЕРЖАВНОГО РЕГУЛЮВАННЯ В СИСТЕМІ СОЦІАЛЬНО-ЕКОНОМІЧНОГО РОЗВИТКУ
}

\begin{abstract}
Анотація. Визначено сутнісні характеристики поняття “міграція”, які прийнято розглядати в системі державного регулювання соиіально-економічних прочесів. Охарактеризовано теоретико-методичні підходи (суспільний, просторовий, регуляторний, розподільний) до трактування міграції та їх відмінності в контексті розроблення державної міграційної політики. Наголошено, щчо міграційні прочеси охоплюють низку видів територіальних переміщень населення: повне переселення, маятникове, сезонне, епізодичне. Узагальнено міждисичиплінарний контекст дослідження міграційних процесів в розрізі базових галузей науки (економіка, демографія, сочіологія, міграціологія, антропологія, політологія, статистика, психологія, історія, юриспруденція). Визначено концептуальні положення міграційних процесів та їх місце при визначенні методичних підходів до забезпечення сочіально-економічного розвитку країни. Виділено форми руху населення (природний, просторовий, соціальний) у системі міграџійних процесів. Зроблено висновок, щуо міграційні процеси мають вплив на всі сторони життєдіяльності людей, суспільства та спричинюють зміни в структурі соціально-економічного розвитку країни. Наведено перелік функцій міграції (прискорювальна, перерозподільна, селективна) та охарактеризовано важливість їх ефективної реалізації у системі державного управління сочіально-економічними змінами. Систематизовано групи факторів (демографічні, економічні, сочіальні, етнічно-культурні, політичні), щуо визначають інтенсивність міграційних прочесів та напрями державної міграчійної політики. Визначено вплив суб'єктивних факторів (географічні, національні, релігійні, суспільно-поведінкові) на міграційні процеси та реалізацію державної міграчійної політики. Виділено інтеграційні особливості міграџійних процесів та їх значення при забезпеченні сочіально-економічного розвитку країни.
\end{abstract}

Ключові слова: міграція, міграційні процеси, державне регулювання, соціально-економічний розвиток.

Barna M. Y.,

martabarna@ukr.net, ORCIDID:0000-0001-5248-9774,

Researcher ID: G-9493-2019,

Doctor of Economics, Professor, First Vice-rector, Professor of the Department of Tourism and Ho-

tel\&Restaurant Business, Lviv University of Trade and Economics, Lviv

\section{CONCEPTUAL FEATURES OF MIGRATION PROCESSES AS AN OBJECT OF STATE REGULATION IN THE SYSTEM OF SOCIO-ECONOMIC DEVELOPMENT}

\begin{abstract}
The essential characteristics of the concept of "migration" are determined, which are considered in the system of state regulation of socio-economic processes. Theoretical and methodological approaches (social, spatial, regulatory, distributive) are described to the interpretation of migration and their differences in the context of developing state migration policy. It is emphasized that migration processes cover a number of types of territorial movements of the population: full resettlement, pendulum, seasonal, episodic. The interdisciplinary context of research of migration processes in the context of basic branches of science (economics, demography, sociology, migration, anthropology, political science, statistics, psychology, history, jurisprudence) is generalized. The conceptual provisions of migration processes and their place in determining the methodological approaches to ensuring the socio-economic development of the country are determined. The forms of population movement (natural, spatial, social) in the system of migration processes are distinguished. It is concluded that migration processes have an impact on all aspects of human life, society and cause changes in the structure of socio-economic development of the country. The list of migration functions (accelerating, redistributive, selective) is given and the importance of their effective realization in the system of state management of social and economic changes is characterized. Systematized groups of factors (demographic, economic,
\end{abstract}


social, ethnic-cultural, political) that determine the intensity of migration processes and directions of state migration policy. The influence of subjective factors (geographical, national, religious, social and behavioral) on migration processes and the implementation of state migration policy is determined. The integration features of migration processes and their importance in ensuring the socio-economic development of the country are highlighted.

Key words: migration, migration processes, state regulation, socio-economic development.

\author{
JEL Classification: F22, J61, O15 \\ DOI: https://doi.org/10.36477/2522-1205-2021-63-03
}

Постановка проблеми. Важливою передумовою розробки та реалізації ефективного механізму державного регулювання міграції є його теоретикометодологічне забезпечення. Зокрема, потребують уточнення основні терміни та поняття, ключовими серед яких у цьому дослідженні є “міграція" та “міграційні процеси". Слово “міграція" походить від латинського “migration”, що в перекладі означає “переселення". У науково-довідковій літературі здебільшого трактування поняття стосується характеристик руху осіб як в межах однієї території (країни), так і поза її межами.

Також досить типовим і поширеним є визначення міграції як характеристики особливостей переміщення осіб через кордони певних територій зі зміною місця проживання назавжди або на більш чи менш тривалий час. Таким чином при формуванні системи державного регулювання в міру забезпечення соціально-економічного розвитку країни варто грунтовно підійти до визначення концептуальних характеристик міграційного процесу.

Аналіз останніх досліджень та публікацій. Проблемам побудови системи державного регулювання та забезпечення соціально-економічного розвитку держави присвячені дослідження таких науковців: В. Апопія, Г. Башнянина, 3. Варналія, О. Ковтуна, П. Куцика, Б. Мізюка, Н. Міценко, Б. Семака та ін.

Результати досліджень таких вчених, як М. Біль, Т. Васильців, А. Збарська, Ю. Іванюк, М. Куницька-Іляш, О. Левицька, Р. Лупак, О. Мульська, є вагомим теоретико-прикладним базисом визначення концептуальних положень державного регулювання міграційних процесів. Разом 3 тим, попри достатню кількість наукових праць 3 питань управління міграційними процесами проблемні питання у даному напрямі залишаються та потребують подальшого наукового дослідження.

Постановка завдання. Метою статті $є$ визначення концептуальних ознак міграційних процесів як об'єкта державного регулювання в системі соціально-економічного розвитку.

Виклад основного матеріалу дослідження. Прийнято розрізняти декілька підходів до трактування міграції. За окремими твердженнями міграцію розглядають як рух осіб з метою реалізації соціально-економічних потреб. Тут враховують не лише просторове переміщення населення, a соціальні тенденції, за умови їх позначення територіальною ознакою. Згідно з іншим підходом поняття “міграція” розглядають як просторовий рух населення, незалежно від його цільових характеристик. Третій підхід при трактуванні міграції стосується визначення поняття як просторового явища, що включає переміщення осіб між населеними пунктами в міру ї зацікавленості (постійної чи тимчасової) змінити місця проживання, а також об'єкта державного регулювання руху населення, враховуючи його проживання та мотивацію при пошуку нових робочих місць. При четвертому підході міграція обгрунтовується як процес просторового переміщення населення, що призводить до його територіального перерозподілу [1, с. 279-306; 2, c. 149-170].

Міграційний процес як складне явище $\epsilon$ предметом дослідження демографії, антропології, статистики, політології, юриспруденції, економіки, соціології, міграціології. На рис. 1 виділено ключові аспекти міграційної проблематики у призмі міждисциплінарного дослідження.

Виходячи зі своєї сутнісної специфіки та використовуючи відповідний інструментарій, кожна наука розглядає окремі аспекти міграції і не може повною мірою охопити вивчення цієї проблеми. Так, комплексністю досліджень вирізняється міграціологія - наука, котра вивчає міграційний рух населення, зумовлений соціально-економічними відносинами, використовуючи при цьому методи i дані суміжних наукових дисциплін (демографії, соціології, права, статистики тощо).

Вчені-міграціологи, так само як і більшість демографів і соціологів, виділяють три форми руху населення: природний (динаміка народжень і смертей), просторовий (переміщення по території) та соціальний (зміна статусу людей в соціальноекономічній структурі суспільства в широкому значенні). Водночас зауважують, що безповоротний рух, тобто переселення, є міграцією у вузькому значенні цього слова. Переміщення населення між населеними пунктами змінює загальну картину розміщення населення в країні (регіоні), створює систему міжпоселенських зв'язків, відіграє важливу роль у територіальному розподілі праці. Тому саме такі переміщення вчені й дефініціюють як міграцію. Рух населення в межах населеного пункту не розглядають як міграцію [3, с. 507-514]. Таким чином, міграцію прийнято розглядати як територіальний рух осіб між населеними пунктами у формі безповоротного, маятникового чи сезонного переміщення. При цьому осіб, які здійснюють відповідні територіальні переміщення, називають мігрантами. 


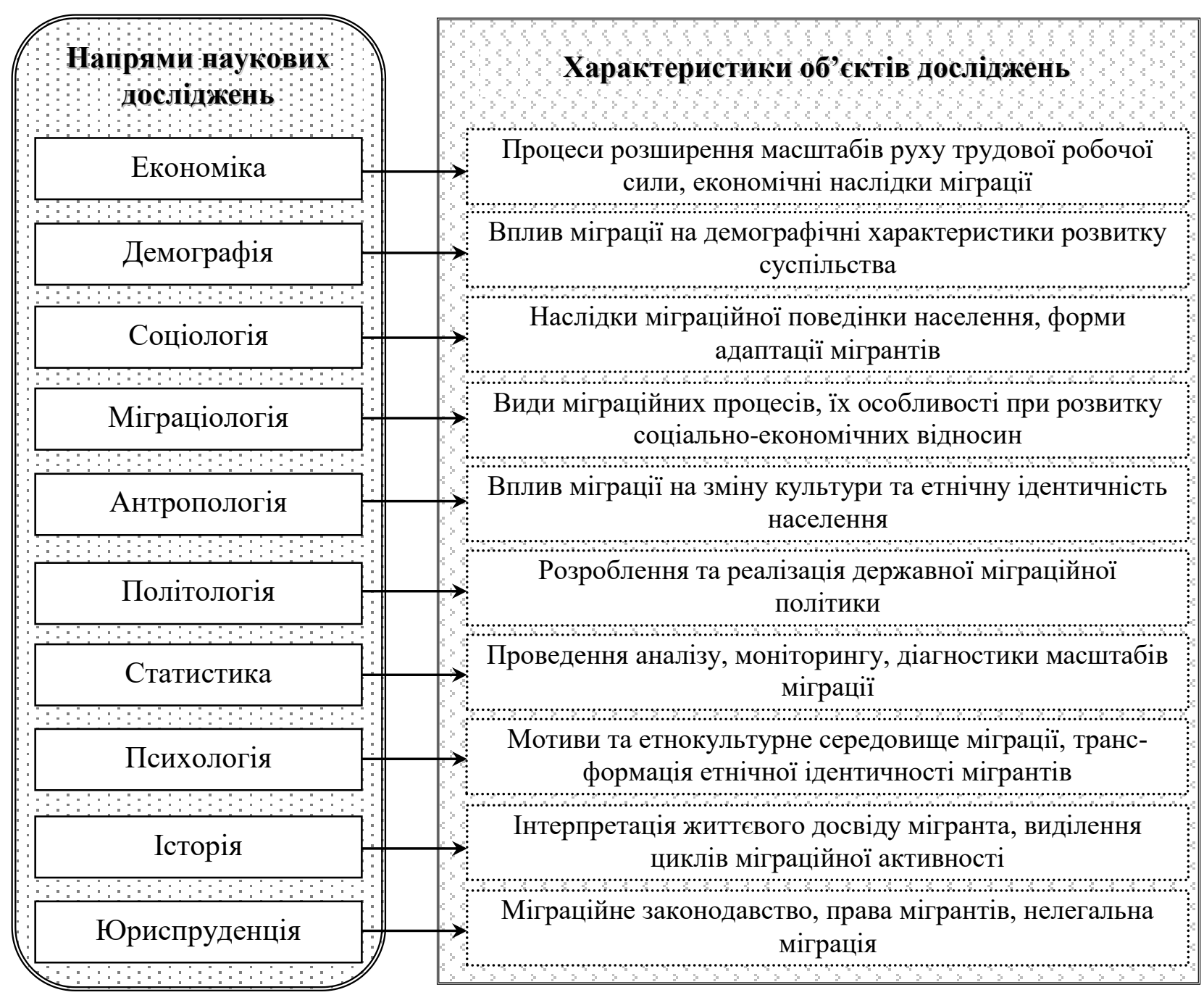

Рис. 1. Міждисциплінарний контекст дослідження міграційних процесів

У широкому розумінні міграційні процеси охоплюють такі види територіальних переміщень населення: переселення, маятникові, сезонні та епізодичні. Таким чином, міграцію можна визначити як територіальне переміщення населення між адміністративними районами, населеними пунктами в межах однієї країни чи через державні кордони, незалежно від мети, тривалості чи регулярності.

Крім того, важливо зауважити, що міграція - це не простий територіальний (просторовий, механічний) рух населення, який тісно взаємопов'язаний із іншими формами його руху, а водночас $\epsilon$ складним соціально-економічним, психологічним процесом, який охоплює практично всі сторони життєдіяльності людей, суспільства в цілому, спричинює зміни в структурі економічної системи та розміщенні основних факторів виробництва країни [4, с. 1699-1729].

Змістовні характеристики міграції населення краще обгрунтувати у тих ролях, де відіграють важливе місце у життедіяльності суспільства, тобто у системі виконання функцій. Так, функції, які не залежать від типу та виду соціально-економічних відносин і особливостей окремих суспільств, прий- нято вважати загальними. Якщо враховувати соціально-економічні умови конкретних країн, функції мотивації варто називати специфічними. Серед найбільш загальних функцій міграції виділяють: прискорювальну, перерозподільну, селективну.

Суть прискорювальної функції полягає не лише у забезпеченні просторової рухливості населення, а й у сприянні зміни соціально-психологічної характеристики людей, розширенні їх світогляду, накопиченні знань в різних сферах життя, обміні досвідом, розвитку особистості в цілому.

Перерозподільна функція міграції пов'язана 3 характеристиками розміщення населення, механізмами розподілу виробничих потужностей та інвестиційного капіталу між окремими регіонами країни чи між різними країнами. Виконуючи цю функцію, міграція не лише збільшує чисельність населення окремих територій, а й може впливати на демографічні процеси, оскільки мігранти беруть участь у відтворенні населення. Тут варто виділити значення міграції у зміні чисельності населення, адже в міру таких тенденцій формується основний соціально-трудовий актив суспільства та забезпечується ефективність його використання. 
Селективна функція передбачає, що нерівномірна участь у міграції різних соціальнодемографічних груп призводить до зміни якісного складу населення різних територій. Дослідники міграції зазначають, що чоловіки більш схильні до міграцій, ніж жінки; працездатне населення частіше мігрує, ніж непрацездатне [5, с. 36-53]. Хоча в умовах глобалізації характер перебігу міграційних процесів і склад мігрантів дещо змінюється.

У науковій літературі поняття міграції населення іноді вживається як збірне поняття та у множині, оскільки воно відображає сукупність міграційних потоків та процесів, що супроводжують практично всі етапи розвитку суспільства. Міграція є одиничною подією для окремої особи. А міграційні потоки складаються 3 сукупності таких переміщень, об'єднаних спільністю напрямку, визначеного регіонами прибуття чи вибуття мігрантів за певний проміжок часу [6, с. 50-58; 7, с. 5-21]. Сукупність тих мігрантів, котрі прибули в певну країну чи регіон в один і той самий часовий період, називають міграційною когортою. Інформація про міграційні когорти є необхідною при дослідженні територіальних та часових закономірностей міграції, виявленні ऑiі впливу на зміну чисельності та складу населення певної території тощо.

На формування і перебіг міграційних процесів впливає ціла низка факторів. Виявлення та вивчення таких факторів набуває особливого значення, коли йдеться про необхідність вибору адекватних регуляторів міграції населення [8, с. 999-1014]. Спираючись на найбільш загальний розподіл факторів на об'єктивні (природні та суспільні) та суб'єктивні, коротко розглянемо основні з них. До об'єктивних природних факторів можна віднести географічне положення території, іiі екологічний стан, геологічні, грунтові, кліматичні та інші умови. Суспільні фактори поділяють на великі групи, серед яких: (1) демографічні (одруження, розлучення, смерть близьких, народження дитини), (2) економічні (рівень оплати праці, стан ринку праці, система оподаткування, інвестиційний клімат), (3) соціальні (якість та доступність освіти, стан системи охорони здоров'я, умови праці, можливості кар'єрного зростання, самореалізації особистості), (4) етнічно-культурні (особливості культури, побуту, загальноприйняті в суспільстві норми та цінності, рівень етнічної, расової толерантності та наявність дискримінації), (5) політичні (рівень демократії, політичної стабільності, корумпованості).

Коли йдеться про добровільну міграцію, то тут вирішальну роль відіграють суб'єктивні фактори. Вони пов'язані з соціально-психологічними властивостями особи, іiі внутрішньою природою (потребами, інтересами, ціннісними орієнтаціями), дотриманням національних традицій, релігійними, політичними переконаннями, стандартами поведінки. Тому власне від суб'єктивних факторів залежить, які саме об'єктивні фактори складають мотиваційну основу міграційної поведінки конкретної особи чи групи осіб. При цьому прийнято під міграційною поведінкою розуміти сукупність дій, вчинків і відносин, пов'язаних 3 міграцією індивідів або відмовою від неї.

Слід зауважити, що на весь процес прийняття рішення щодо міграції та реалізацію цього рішення впливає ціла низка факторів - як регіону проживання особистості, так i приймаючого соціуму (регіону чи країни призначення). Ці фактори, відповідно, можуть служити виштовхуючими та притягуючими. Якщо особа негативно оцінює регіон свого постійного проживання при позитивній оцінці можливостей працевлаштування i життя за кордоном, то у неї формується міграційна мотивація [9, с. 51-67]. Відтак міграційна мотивація - це рушійна сила поведінки людини, що спонукає iii до здійснення міграції 3 метою задоволення індивідуальних та суспільних потреб, досягнення певних цілей.

Міграційну готовність визначають як інтегративне утворення, яке за своєю суттю є установкою на зміну місця проживання та прикладання праці [10, с. 1093-1123]. Очевидно, в деяких випадках поняття міграційної готовності та потенційної міграції можна було б вживати як синоніми. Однак, враховуючи, що в структурі міграційної готовності психологи виділяють також поведінкову складову (поряд 3 когнітивною та емоційно-оцінною), варто визнати, що вона $є$ найближчим кроком на шляху до здійснення самого міграційного переміщення.

Висновки i перспективи подальших досліджень у даному напрямі. Трансформація суспільних та економічних відносин обумовлює структурні зрушення на ринку праці. Посилення міграційної активності населення, особливо серед висококваліфікованих кадрів, розвиток економіки знань, інформаційних технологій та поява нових неформальних форм праці зумовлюють необхідність оновлення механізмів державного регулювання міграції та реформування ринку праці. Сучасні тенденції на ринку праці з посиленими міграційними процесами стають показником соціальноекономічного розвитку країни чи окремого регіону. Водночас в міру постійних соціально-економічних тенденцій досить складно сформувати усталені базові характеристики міграційних процесів, що у перспективі визначає необхідність подальших досліджень чинників, умов, інструментів, методичних підходів реалізації державної міграційної політики.

\section{ЛІТЕРАТУРА}

1. High skilled migration through the lens of policy / Parsons C., Rojon S., Rose L., Samanani F. // Migration Studies. - 2020. - Vol. 8. Is. 3. - P. 279-306.

2. Instruments of regional policy for human resources conservation by means of regulation of external youth migration of rural territories of the Carpathian region / Vasyltsiv T., Lupak R., KunytskaIliash M., Levytska O., Mulska O. // Agricultural and Resource Economics. - 2020. - Vol. 6. № 3. - P. 149. 170.

3. Modelling the conditions affecting population migration activity in the Eastern European region: the case of Ukraine / Levytska O., Mulska O., Ivaniuk U., 


\section{Herald of Lviv University of Trade and Economics. Economic Sciences. № 63, 2021}

Kunytska-Iliash M., Vasyltsiv T., Lupak R. // TEM Journal. - 2020. - Vol. 9. Is. 2. - P. 507-514.

4. Arif I. The determinants of international migration: Unbundling the role of economic, political and social institutions / Arif I. // World Economy. 2020. - № 43(6). - P. 1699-1729.

5. Balaz V. Migration decision making as complex choice. Eliciting decision weights under conditions of imperfect and complex information through experimental methods / Balaz V., Williams A., Fifeková E. // Population, Space and Place. - 2014. № 22(1). - P. 36-53.

6. Vasyltsiv, T. G. Social Security of Ukraine and the EU: aspects of convergence and improvement of migration policy / Vasyltsiv T. G., Lupak R. L., Kunytska-Iliash M. V. // Baltic Journal of Economic Studies. - 2019. - Vol. 5. № 4. - P. 50-58.

7. Bil M. Migration and human development in Ukraine: features of interaction and priorities of state regulation / Bil M., Barna M., Zbarska A. // Agricultural and Resource Economics. - 2021. - Vol. 7. № 3. - P. 5-21.

8. Scheibelhofer E. Shifting migration aspirations in second modernity / Scheibelhofer E. // Journal of Ethnic and Migration Studies. - 2018. - № 44(6). P. 999-1014.

9. Vasyltsiv T. Trends and characteristics of The migration from Ukraine to Poland: the aspect of rural areas and conclusion for state migration policy / Vasyltsiv T., Lupak R., Levytska O. // Wieś i Rolnictwo. - 2020. - № 186(1). - C. 51-67.

10. Borjas G. Welfare reform and immigrant participation in welfare programmes / Borjas G. // International Migration Review. - 2002. - № 36(4). P. 1093-1123.

\section{REFERENCES}

1. Parsons C., Rojon S., Rose L. and Samanani F. (2020), High skilled migration through the lens of policy, Migration Studies, Vol. 8. Is. 3, p. 279-306.

2. Vasyltsiv T., Lupak R., Kunytska-Iliash M., Levytska O. and Mulska O. (2020), Instruments of regional policy for human resources conservation by means of regulation of external youth migration of rural territories of the Carpathian region, Agricultural and Resource Economics, Vol. 6. № 3, p. 149-170.

3. Levytska O., Mulska O., Ivaniuk U., KunytskaIliash M., Vasyltsiv T. and Lupak R. (2020), Modelling the conditions affecting population migration activity in the Eastern European region: the case of Ukraine, TEM Journal, Vol. 9. Is. 2, p. 507-514.

4. Arif I. (2020), The determinants of international migration: Unbundling the role of economic, political and social institutions, World Economy, № 43(6), p. $1699-1729$.

5. Balaz V., Williams A. and Fifeková E. (2014), Migration decision making as complex choice. Eliciting decision weights under conditions of imperfect and complex information through experimental methods, Population, Space and Place., № 22(1), p. 36-53.

6. Vasyltsiv, T. G., Lupak, R. L. and KunytskaIliash, M. V. (2019), Social Security of Ukraine and the EU: aspects of convergence and improvement of migration policy, Baltic Journal of Economic Studies, Vol. 5. № 4, p. 50-58.

7. Bil M., Barna M. and Zbarska A. (2021), Migration and human development in Ukraine: features of interaction and priorities of state regulation, Agricultural and Resource Economics, Vol. 7. № 3, p. 5-21.

8. Scheibelhofer E. (2018), Shifting migration aspirations in second modernity, Journal of Ethnic and Migration Studies, № 44(6), p. 999-1014.

9. Vasyltsiv T., Lupak R. and Levytska O. (2020), Trends and characteristics of The migration from Ukraine to Poland: the aspect of rural areas and conclusion for state migration policy, Wieś i Rolnictwo, № 186(1), c. 51-67.

10. Borjas G. (2002), Welfare reform and immigrant participation in welfare programmes, International Migration Review, № 36(4), p. 10931123.

Стаття надійшла до редакиії 10 травня 2021 року 